\title{
Drying of microalga Scenedesmus obliquus BR003 in a gas dryer at low temperatures
}

\author{
Andry Caroline de Melo Aguiar ${ }^{1}$ Marcio Arêdes Martins ${ }^{1 *}$ (i) Rúben Christian Barbosa ${ }^{1}$ \\ Jaime Daniel Bustos-Vanegas ${ }^{1}$ Jimmy $_{\text {Soares }}{ }^{1}$ (D) Mauricio de Oliveira Leite ${ }^{1}$ \\ Dilson Novais Rocha ${ }^{1}$ Arthur Freitas Gomes ${ }^{1}$ Gabriela de Castro Bechara ${ }^{1}$
}

\begin{abstract}
${ }^{1}$ Departamento de Engenharia Agrícola, Universidade Federal de Viçosa (UFV), 36570-900, Viçosa, MG, Brasil. E-mail: aredes@ufv.br ${ }^{*}$ Corresponding author.

RESUMO: O desenvolvimento de equipamentos eficientes e especificos para a secagem de microalgas é essencial para a exploração comercial destes microrganismos que apresentam alta taxa de crescimento e grande potencial biotecnológico. Os custos de secagem da biomassa de microalgas ainda são elevados e precisam ser reduzidos para a produção de compostos com baixo valor agregado. Portanto, realizou-se o estudo da secagem da microalga Scenedesmus obliquus BR003 utilizando baixas temperaturas. S. obliquus BR003 é uma microalga robusta que apresenta alta produtividade de lipídeos. Em escala laboratorial, observou-se que a biomassa de S. obliquus BR003 foi rapidamente seca em baixas temperaturas entre 50 e $60^{\circ} \mathrm{C}$. Um secador a gás foi utilizado para avaliar a secagem da biomassa de S. obliquus BR003 em escala piloto. A biomassa foi seca em menos de 24 h utilizando o secador a gás, entretanto, a elevada umidade da biomassa da microalga requereu uma maior renovação de ar na câmara do secador. A análise de fluidodinâmica computacional do secador a gás mostrou dois parâmetros importantes para se obter uma maior efetividade de transferência de calor e massa durante o processo de secagem da biomassa de microalga. Concluiu-se que um secador a gás adequado, para a biomassa de microalgas, deve possuir múltiplos pontos de injeção de ar, e um eficiente sistema de circulação e renovação de ar no interior da câmara de secagem.

Palavras-chave: fluidodinâmica computacional, escala piloto, secagem de biomassa, produção de lipídeos.
\end{abstract}

Secagem da microalga Scenedesmus obliquus BR003 em secador a gás em baixas temperaturas

ABSTRACT: Development of efficient and specific equipment to dry microalgae is essential for commercial use of these microorganisms that show high growth rates and biotechnological potential. Drying costs of microalgae biomass are still high and they should be reduced for the production of compounds with low added value. Therefore, we evaluated the drying process of the microalga Scenedesmus obliquus BR003 using low temperatures. S. obliquus BR003 is a robust microalga that shows high lipid productivity. At laboratory scale, it was observed that the biomass of S. obliquus BR003 was rapidly dried at low temperatures between 50 and $60^{\circ} \mathrm{C}$. A gas dryer was used to evaluate the drying of the biomass of S. obliquus BR003 on a pilot-scale. The biomass was dried in less than $24 \mathrm{~h}$ using the gas dryer; however, the high moisture of the microalga biomass required a higher air renovation in the drying chamber. Computational fluid dynamics analysis of the gas dryer showed two important parameters to achieve greater effectiveness of heat and mass transfer rates during the drying process of the microalga biomass. It was concluded that a gas dryer suitable for the microalgae biomass should have multiple air injection points, and an efficient circulation and renovation system of air inside the drying chamber.

Key words: computational fluid dynamics analysis, pilot-scale, biomass drying, lipid production.

\section{INTRODUCTION}

Microalgae are a promising source of biomass that can be produced on unsuitable lands for agriculture. They can be used as raw material in several processes converting biomass into energy. Microalgae strains with high lipid productivity are suitable for synthesizing biodiesel, while strainswith high content ofcarbohydratesare used for the production of bioethanol (SINGH; OLSEN, 2011). When compared to terrestrial plants, microalgae show several advantages such as shorter crop cycles (e.g. 20 days),higher efficiency in conversion of sunlight and nutrients in biomass, and they produce ten times more oil per unit of area (BRENNAN; OWENDE, 2010).

Microalgae production workflow is divided into five basic steps: cultivation, harvesting, drying, storage, and extraction of biocompounds.A current challenge for the commercial production of microalgae is the drying process that corresponds toapproximately $30 \%$ of total production costs (BRENNAN; OWENDE, 2010). Microalgae produced under photoautotrophic growth conditions show a biomass concentration between 0.5 and 5 $\mathrm{gL}^{-1}$ at the end of the cultivation (FAN et al., 2015). Therefore, biomass drying is necessary to improve 
the extraction of metabolites (BAGCHI, 2001; RAO; MALLICK, 2015), such as lipids which are extracted using non-polar solvents.

Drying of the microalgae biomass is often carried in closed systems which are not economically feasible for production of biofuels, like spray-drying and lyophilization (BAGCHI, 2001; RAO; MALLICK, 2015). Spray-drying consists in the atomization of microalgae culture which is dried using awarm air stream (SHOW; LEE; CHANG, 2013).Lyophilization consists in the removal of water by sublimation of the frozen biomass in a negative pressure chamber. Although, lyophilization preserves the main compositional characteristics of the microalgae, the costs of equipment and operation are prohibitive for low value-added products (SHOW et al., 2015). Sundrying method is also suggested for microalgae crops because it shows lower operational costs compared to other drying processes. However, sun-drying method is a slow process, susceptible to contamination and biomass loss; and it also requires large drying surfaces (BRENNAN; OWENDE, 2010).

It has been shown that the convection-based method is a promising alternative to dry the biomass of Scenedesmus sp. However, it was observed that the biomass thickness is an important parameter to develop an efficient drying process(BAGCHI, 2001; RAO; MALLICK, 2015).Indeed, microalgae biomass drying processes are still little understood, and pilotscale studies are required for the development of specific microalgae-drying equipment.

In this current study we evaluated thetechnical viability of a gas dryer using the biomass of S. obliquus BR003.This microalga strainshowed higher production of biomass and lipids compared to other freshwater microalgae genus; moreover,this strain showed a fast growth in different culture media using different fertilizers(ROCHA et al., 2017; SOARES et al., 2018). First, the drying of S. obliquus BR003 biomass was evaluated on a laboratory scale using different parameters. Then, drying kinetics of the microalga biomass was carried using a gas dryer with different configurations. Computational fluid dynamics analysis was used to analyze the flow in the gas dryer in order to suggest possible improvements in the development of an equipmentspecific for microalgae biomass.

\section{MATERIAL AND METHODS}

\section{Strain and biomass production}

The microalga $S$. obliquus BR003 was obtained from the Collection of Cyanobacteria and
Microalgae of the Department of Plant Biology, Universidade Federal de Viçosa (Minas Gerais, Brazil). S. obliquus BR003 was cultivated in the pilot-plant of microalgae biomass production at the Biofuels Laboratory of the Department of Agricultural Engineering, Universidade Federal de Viçosa (Minas Gerais, Brazil). Cultivation of $S$. obliquus BR003 was carried out in a raceway tank during 15 days. Temperature of the culture varied between 22 and 30 ${ }^{\circ} \mathrm{C}$, and the average of the natural light intensity was $632 \mu \mathrm{mols} \mathrm{m}^{-2} \mathrm{~s}^{-1}$. Microalga nutrition was provided using a culture medium based on inorganic agricultural fertilizers. The microalga culture was transferred to a decanter when reached the stationary phase, and the $\mathrm{pH}$ was adjusted to 10 using sodium hydroxide, then a cationic polymer flocculant was added at a concentration of $10 \mathrm{ppm}$. The culture was mixed at $50 \mathrm{rpm}$ for $5 \mathrm{~min}$, and the flocculated biomass was recovered after $2 \mathrm{~h}$ and stored at $-20{ }^{\circ} \mathrm{C}$. Microalga biomass was thawed at 25 ${ }^{\circ} \mathrm{C}$ for $12 \mathrm{~h}$ prior to the use in the drying experiments.

\section{Determination of dry weight}

The dry weight of S. obliquus BR003 was determined by the gravimetric method using $5 \mathrm{~g}$ of fresh sample (BOROWITZKA; MOHEIMANI, 2013). Glassware used in the determination of the dry weight was previously dried at $102{ }^{\circ} \mathrm{C}$ for $1 \mathrm{~h}$ in an oven with forced air circulation.

\section{Microalga drying in incubator}

S. obliquus BR003 biomass was dried using different temperatures in an incubator (Ethik 4300 FRDPE, Brazil). The temperatures of 40, 50, and $60{ }^{\circ} \mathrm{C}$ were used to dry the biomass with a sample thickness of $1 \mathrm{~cm}$ during 12 and $24 \mathrm{~h}$. Biomass thickness slice was measured using a caliper. The time of drying was determined in $24 \mathrm{~h}$ to avoid degradation of the microalga biomass. After the biomass drying in the incubator, samples were transferred to an oven with forced air circulation at $102{ }^{\circ} \mathrm{C}$ for $12 \mathrm{~h}$ to determine drying efficiency. The experiment was performed in quadruplicate.

\section{Drying kinetics of the microalga using a gas dryer}

S. obliquus BR003 biomass was dried in a gas dryer in order to evaluate drying conditions on a pilot-scale. Samples were transferred to pre-weighted aluminum trays. A biomass thickness of $1 \mathrm{~cm}$ was used and the fresh weight was $113 \pm 2 \mathrm{~g}$. Trays with S. obliquus BR003 were weighed, and the biomass was dried using the gas dryer. The effect of the air renovation inside the gas drying chamber was evaluated using two configurations of the air outlet: totally open or obstructed 
by $50 \%$. The gas dryer was $0.12 \mathrm{~m}^{3}$ with capacity for 8 trays of $50.5 \times 40.5 \times 2.5 \mathrm{~cm}$ (width $\times$ depth $\times$ height), the diameter of the air outlet varied from 0 to $66 \mathrm{~cm}^{2}$, the diameter of the air inlet was $9.5 \mathrm{~cm}$ and it was connected in $\mathrm{a} \frac{1}{2} \mathrm{cv}$ fan engine.

Temperature inside the chamber was $54 \pm$ $3{ }^{\circ} \mathrm{C}$. The temperature inside the dryer was controlled by varying the gas flow rate. Trays with $S$. obliquus BR003 were weighed at intervals of $1 \mathrm{~h}$ until they reached the constant mass. The air outlet of the gas dryer was monitored using a portable digital thermohygrometer (THAR-185, Instrutherm, Brazil). The experiment was performed in triplicate.

\section{Computational fluid dynamics for the gas dryer}

Computational fluid dynamics analysis was used to evaluate the airflow in the gas dryer, and identify flow patterns and regions in which heat and mass transfer phenomena are limited. The two simulated conditions of the gas dryer were air outlet totally open and obstructed by $50 \%$. Percentage of recirculated air was increased when the air outlet was obstructed by $50 \%$ to minimize consumption of gas in the burner.

Geometry of the model was created using the software Ansys Design Modeler (version 11.0). Discretization of the fluid domain used the software Ansys Meshing (version 11.0). The mesh independence test was assessed, and a mesh of 584,008 tetrahedral elements was defined with refinement in the mixing region and the step apertures for the drying chamber. Based on the geometry of the gas dryer and the flow rate in the recirculation duct, a time interval of $0.2 \mathrm{~s}$ was defined.

The problem was addressed in a permanent regime, solving equations of mass conservation, momentum and energy in differential form (Equations 1 to 3 ) for the fluid domain (air considered as ideal gas). Implementation of the model was performed using the software Ansys CFX (version 11.0).

$$
\begin{aligned}
& \nabla \cdot(\rho \vec{v})=0 \\
& \nabla \cdot(\rho \vec{v} \vec{v})=-\nabla p+\mu \nabla^{2} \vec{v}+\rho \vec{g} \\
& \nabla \cdot(c \rho T \vec{v})=\nabla \cdot(k \nabla T)
\end{aligned}
$$

The terms on the left side of equations 1 to 3 represent advective transport. Forces acting on the fluid are represented by the terms on the right side of equation 2, and corresponded to pressure, viscous and buoyancy forces. The Boussinesq approximation was used to model the buoyancy force (BUSTOS-VANEGAS et al., 2018). Forced ventilation generated turbulent flow conditions, which was characterized by a Reynolds number of 7,270 . Thus, to monitor turbulent fluctuations of the transported properties, the governing equations were considered as Reynolds-averaged Navier-Stokes equations and the additional term in the moment equation, Reynolds tensor, was solved using the k- $\omega$ model available on the CFX platform.

\section{Boundary conditions}

The fan provides constant flow of moist air from the drying chamber and injecting it into the recirculation duct. Based on the experimental duct velocity measurement $\left(1 \mathrm{~m} \mathrm{~s}^{-1}\right)$, a mass flow rate of $0.0192 \mathrm{~kg} \mathrm{~s}^{-1}$ was defined as a boundary condition at the moist air outlet and inlet of the recirculation duct. Non-slip boundary condition was defined for the walls. The zero-pressure condition was established on the warm air inlet for gas dryer and air outlet for the environment at the top of the recirculation duct. Thermal resistance method was used to calculate the overall heat transfer coefficient at the walls. The external environmental temperature was set at $25^{\circ} \mathrm{C}$. The thinner metallic walls of the drier do not have significant thermal resistance; therefore, the overall heat transfer coefficient accounts for convection and radiation, and was calculated for each wall according to BUSTOS-VANEGAS et al. (2018).

\section{RESULTS AND DISCUSSION}

\section{Microalga drying in an incubator using different temperatures}

The $S$. obliquus BR003 biomass was dried in an incubator using different temperatures aiming a reduction of energy consumption in microalgae crops. Mild drying temperatures from 40 to $60{ }^{\circ} \mathrm{C}$ were used to avoid overheating and alterations in the biomass quality (SHOW et al., 2015). The $S$. obliquus BR003 biomass was harvested and submitted to a dewatering process using flocculation. It was observed that the biomass showed a high moisture of $87.6 \pm 1.7 \%$ $\left(\mathrm{m} \mathrm{v}^{-1}\right)$ after the dewatering step. However, the use of mild drying temperatures showed great effected on the reduction of biomass moisture, and drying efficiencies higher than $94 \%$ were observed using the different temperatures (Figure 1A). Indeed, drying efficiencies higher than $97 \%$ were observed after $12 \mathrm{~h}$ of drying in an incubator at 50 and $60^{\circ} \mathrm{C}$, and a minimum variation in weight was observed after drying the biomass in an oven with forced air circulation for another $12 \mathrm{~h}$ at $102{ }^{\circ} \mathrm{C}$ (Figure 1A). The biomass drying process occurred over a relatively short interval; thus, high temperatures that could exert undesired changes on the biochemical properties of the microalga biomass were not evaluated in this study. It was observed that sensorial properties such as color and odor of $S$. 

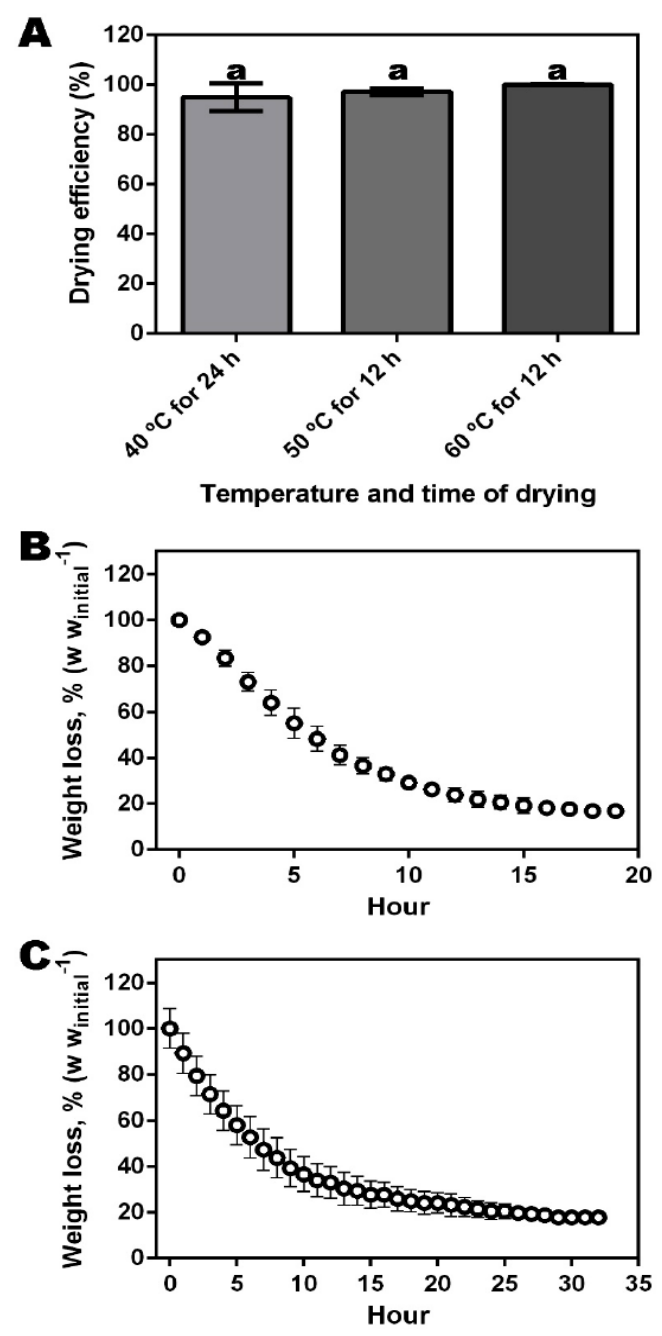

Figure 1 - (A) Drying efficiency of the biomass of $S$. obliquus BR003 using different temperatures and biomass thickness of $1 \mathrm{~cm}$. Biomass was dried for $24 \mathrm{~h}$ at $40{ }^{\circ} \mathrm{C}$, and $12 \mathrm{~h}$ at 50 and $60{ }^{\circ} \mathrm{C}$. Bars containing different letters differ from each other by Tukey test at $1 \%$. Drying kinetics of S. obliquus BR003 biomass at $54{ }^{\circ} \mathrm{C}$ using the gas dryer with the air outlet (B) totally open or (C) obstructed by $50 \%$.

obliquus BR003 biomass were preserved. Therefore, the ideal minimum temperature for the drying of the microalga biomass used in this study was $50^{\circ} \mathrm{C}$.

Different temperatures from 40 to $60{ }^{\circ} \mathrm{C}$ resulted in statistically equal drying efficiencies (Figure 1A). However, the drying process was $12 \mathrm{~h}$ longer when $40{ }^{\circ} \mathrm{C}$ was used in contrast with 50 and $60^{\circ} \mathrm{C}$. The use of temperatures in the range of 30 to
$40{ }^{\circ} \mathrm{C}$ requires longer drying processes, and they may induce the growth of other undesired microorganisms that compromise the quality of the microalga biomass. Our results are in agreement with a previous study using Scenedesmus sp. that showed a $90 \%$ removal of moisture after $15 \mathrm{~h}$ at $60^{\circ} \mathrm{C}$ using a biomass thickness of $1 \mathrm{~cm}$ (BAGCHI, 2001; RAO; MALLICK, 2015). We evaluated the use of biomass thickness of 2.5 and $5 \mathrm{~cm}$, but the drying efficiency was reduced and it was not possible to dry the biomass in a reasonable period of time (i.e. $12 \mathrm{~h}$ ) (data not reported).

It was possible to dry the S. obliquus BR003 biomass using the convection-based drying method at low temperatures (e.g. 50 to $\left.60{ }^{\circ} \mathrm{C}\right)$ and short-times (e.g. $12 \mathrm{~h}$ ) (Figure 1A). Other types of dryers also showed to be efficient to dry the microalgae biomass at low temperatures, such as solar dryers and spray dryers. However, solar dryers are susceptible to weather fluctuations, and other drying methods are often required to achieve high drying efficiencies (BOROWITZKA; MOHEIMANI, 2013). Spray dryers required a large amount of energy; and therefore, are not feasible for production of low value-added products like biofuels (BAGCHI, 2001; RAO; MALLICK, 2015). Thus, we choose a gas dryer to evaluate the drying kinetics of $S$. obliquus BR003 biomass on a pilot-scale.

\section{Drying kinetics of the microalga using a gas dryer}

We evaluated the drying kinetics of S. obliquus

BR003 biomass using a gas dryer in order to check the scalability and feasibility of this process in microalgae crops. The biomass was dried using a biomass thickness of $1 \mathrm{~cm}$. The air outlet of the gas dryer was used totally open or obstructed by $50 \%$ in order to evaluate the effect of air renovation inside the gas drying chamber.

It was possible to dry the microalga biomass in less than $24 \mathrm{~h}$ using the gas dryer configured with the air outlet totally open (Figure 1B). A weight loss of $84 \%$ in comparison to the initial biomass was observed after $20 \mathrm{~h}$ (Figure 1B). Conditions of the gas dryer configured with the air outlet totally open during the microalga biomass drying test were: inlet air temperature of $250{ }^{\circ} \mathrm{C}$, outlet air temperature of $45^{\circ} \mathrm{C}$, mean temperature in the drying chamber of 54 ${ }^{\circ} \mathrm{C}$, and mean velocity in the air outlet of $47.8 \mathrm{~km} \mathrm{~h}^{-1}$.

Obstruction of the air outlet by $50 \%$ was achieved reducing the exhaust area from $7 \mathrm{~cm}$ to 3.5 $\mathrm{cm}$ aiming a higher air recirculation inside the gas chamber. However, the obstruction of the air outlet in the gas dryer negatively affected the drying efficiency, and the drying time was increased from $16 \mathrm{~h}$ (Figure 1B) to $29 \mathrm{~h}$ (Figure 1C). Conditions of the gas dryer configured with the air outlet obstructed by $50 \%$ were: 
inlet air temperature of $250^{\circ} \mathrm{C}$, outlet air temperature of $45^{\circ} \mathrm{C}$, mean temperature in the drying chamber of $54{ }^{\circ} \mathrm{C}$, and mean velocity in the air outlet of 33 $\mathrm{km} \mathrm{h}^{-1}$. The gas dryer configured with the air outlet obstructed by $50 \%$ resulted in a biomass weight loss of $82 \%$ evidencing a slower drying process compared to the gas dryer settled with the air outlet totally open (Figures 1B and 1C). Further, we used computational fluid dynamics analysis to better understand the observed phenomena of the drying kinetics of the $S$. obliquus BR003 biomass using a gas dryer.

Analysis of flow in the gas dryer using computational fluid dynamics analysis

The geometry and mesh of the gas dryer are described in the figure 2A. Gas flow analyses showed the warm air and recirculated air streams entering in the drying chamber and exiting the exhaust fan (Figures 2B and 2C). The gray shaded region represents the dead volume in the gas dryer in which the mass transfer coefficient $\left(\mathrm{h}_{\mathrm{m}}\right)$ and convective heat transfer coefficient $(\mathrm{h})$ were limited to less than 0.003 $\mathrm{m} \mathrm{s}^{-1}$ and $2.3 \mathrm{~W} \mathrm{~m}^{-2} \mathrm{~K}^{-1}$, respectively. Air recirculation in the gas dryer with the air outlet totally open was $34 \%$ (Figure 2B), while the partial obstruction of the air outlet resulted in an air circulation of $47 \%$ (Figure 2C). Obstruction of the air outlet by $50 \%$ resulted in a higher air recirculation and reduced regions of dead volume from $18.8 \%$ to only $5.4 \%$.

Computational fluid dynamics analysis of the gas dryer operating with the air outlet totally opened allowed to verify that advection and buoyancy forces

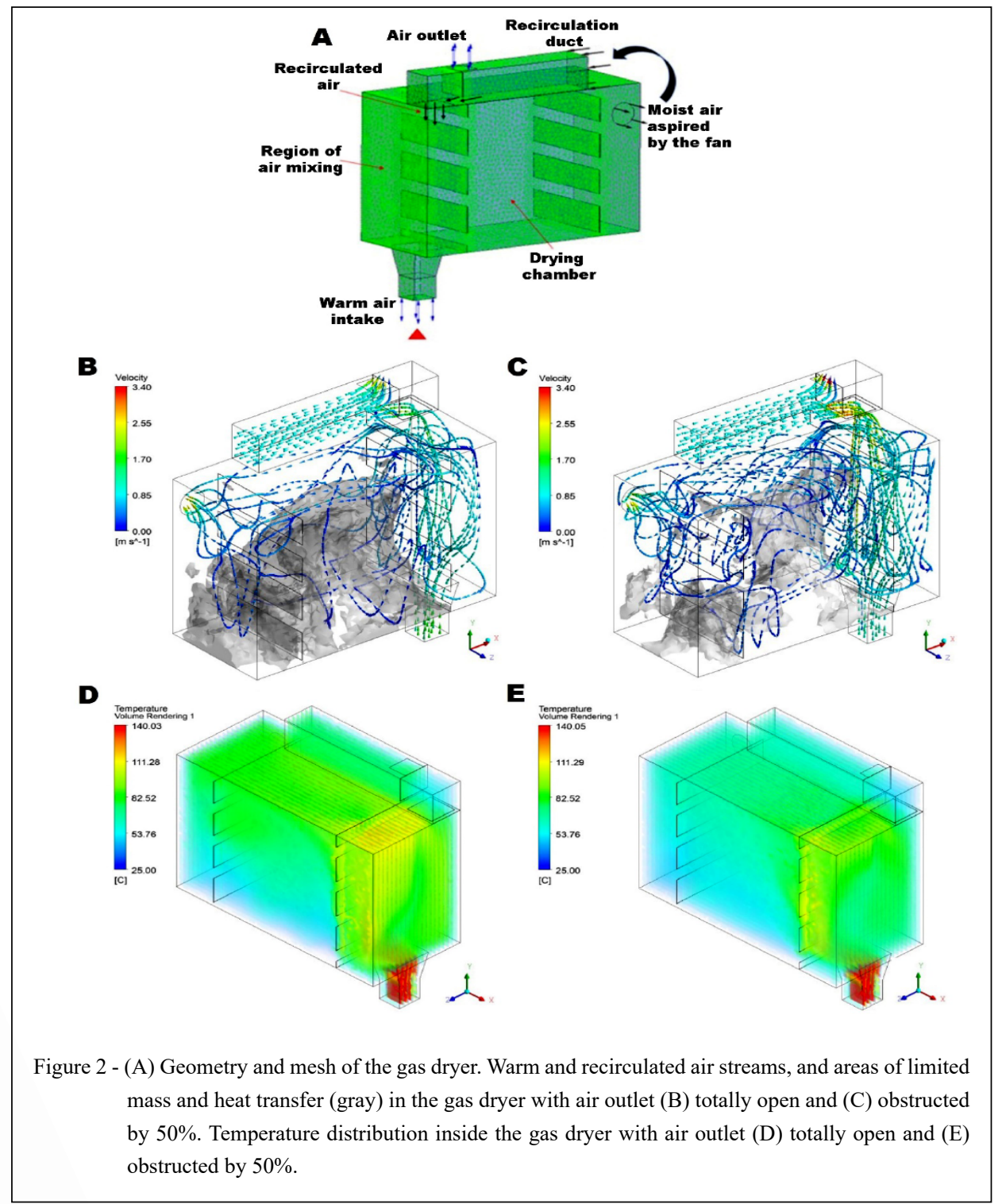

Ciência Rural, v.49, n.7, 2019. 
direct the flow to the top of the chamber, leaving areas of limited mass and heat transfer in the lower region (Figure 2B). Conversely, obstruction of the air outlet by $50 \%$ dryer resulted in a mixing of the recirculated air and warm air improving the distribution of air inside the drying chamber; thus, higher heat and mass transfer coefficients were observed.

Distribution of temperature inside the gas dryer operating with the air outlet totally open and obstructed by $50 \%$ is shown in the figures $2 \mathrm{D}$ and $2 \mathrm{E}$, respectively. Obstruction of the air outlet by $50 \%$ resulted in an increase of the temperature homogeneity in contrast to the air outlet totally open (Figures 2D and 2E). These models corroborate with the air streams of the figures $2 \mathrm{~B}$ and $2 \mathrm{C}$ that shows the influence of the advective term in the transport of thermal energy.

Increasing in the air recirculation resulted in more homogeneous flow and temperature inside the gas dryer (Figures $2 \mathrm{C}$ and $2 \mathrm{E}$ ). However, it was necessary to dry the $S$. obliquus BR003 biomass for a longer period when the gas dryer was settled with the air outlet obstructed by $50 \%$. This phenomenon is due to the high moisture of the $S$. obliquus BR003 biomass. Microalgae biomass showed a high moisture content even when submitted to a dewatering process like the flocculation used in the current study (Figures $2 \mathrm{~B}$ and $2 \mathrm{D}$ ), and this excess of water causes a rapid saturation of the air inside the drying chamber which reduces the process efficiency. Those results suggested that closed dryers specific for the drying of microalgae biomass should operate with lower recirculation rates and air deflector baffles should be installed to improve the mixing and renewal of air inside the drying chamber. Further simulations might be performed using different configurations of the dryer such as the use of deflector plates, insertion of warm air points and development of an efficient recirculation system.

\section{CONCLUSION}

Development of efficient and specific dryers for microalgae biomass is essential for commercial production of several low value-added products like biofuels. The use of a convectionbased drying method successfully reduced the moisture of the $S$. obliquus BR003 biomass using low temperatures between 50 and $60{ }^{\circ} \mathrm{C}$ in a short time. Computational fluid dynamics analysis showed that the air renewal inside the dryer is an important parameter for efficient drying of microalgae biomass with high moisture content even when submitted to a previous dewatering process. Thus, the development of a gas dryer specifically for microalgae should have different points of warm air injection and recirculation.

\section{ACKNOWLEDGEMENTS}

We are thankful to Brazilian National Council for Scientific and Technological Development (CNPq, grants 307147/2015-0 and 140609/2016-4) and FAPEMIG (APQ-0135714) for the scholarships. This study was financed in part by the Coordenação de Aperfeiçoamento de Pessoal de Nível Superior Brazil (CAPES) - Finance Code 001.

\section{DECLARATION OF CONFLICT OF INTERESTS}

The authors declare no conflict of interest. The founding sponsors had no role in the design of the study; in the collection, analyses, or interpretation of data; in the writing of the manuscript, and in the decision to publish the results.

\section{AUTHORS' CONTRIBUTIONS}

The authors contributed equally to the manuscript.

\section{REFERENCES}

BAGCHI, S. K. et al. Development of an oven drying protocol to improve biodiesel production for an indigenous chlorophycean microalga Scenedesmus sp. Bioresource Technology. v.180, p.207-213, 2001. Available from: <https://doi.org/10.1016/j.biortech.2014.12.092>. Accessed: Feb. 19, 2019. doi: 10.1016/j.biortech.2014.12.092.

BOROWITZKA, M. A.; MOHEIMANI, N. R. Algae for biofuels and energy. Dordrecht: Springer Dordrecht, 2013. 5v.

BRENNAN, L.; OWENDE, P. Biofuels from microalgae - a review of technologies for production, processing, and extractions of biofuels and co-products. Renewable and Sustainable Energy Reviews. v.14, p.557577, 2010. Available from: <https://doi.org/10.1016/j.rser.2009.10.009>. Accessed: Oct. 05, 2018. doi: 10.1016/j.rser.2009.10.009.

BUSTOS-VANEGAS, J. D. et al. Thermal inertia effects of the structural elements in heat losses during the charcoal production in brick kilns. Fuel. v.226, p.508-515, 2018. Available from: $<$ https:// doi.org/10.1016/j.fuel.2018.04.024>. Accessed: Feb. 27, 2019. doi: 10.1016/j.fuel.2018.04.024.

FAN, J. et al. Genomic foundation of starch to lipid switch in oleaginous Chlorella. Plant Physiology. v.169, p.2444-2461, 2015. Available from: <https://doi.org/10.1104/pp.15.01174>. Accessed: Feb. 25, 2019. doi: 10.1104/pp.15.01174.

ROCHA, R. P. et al. Exploring the metabolic and physiological diversity of native microalgal strains (Chlorophyta) isolated from tropical freshwater reservoirs. Algal Research. v.28, p.139-150, 2017. Available from: $<$ https://doi.org/10.1016/j.algal.2017.10.021>. Accessed: Oct. 09, 2018. doi: 10.1016/j.algal.2017.10.021.

SHOW, K.Y. et al. Algal biomass dehydration. Bioresource Technology. v.135, p.720-729, 2013. Available from: <https://doi. 
org/10.1016/j.biortech.2012.08.021>. Accessed: Feb. 15, 2018. doi: 10.1016/j.biortech.2012.08.021.

SHOW, K.Y. et al. Microalgal drying and cell disruption - recent advances. Bioresource Technology. v.184, p.258-266, 2015. Available from: <https://doi.org/10.1016/j.biortech.2014.10.139>. Accessed: Oct. 5, 2018. doi: 10.1016/j.biortech.2014.10.139.

SINGH, A.; OLSEN, S. I. A critical review of biochemical conversion, sustainability and life cycle assessment of algal biofuels. Applied Energy. v.88, p.3548-3555, 2011. Available from: <https://doi.org/10.1016/j. apenergy.2010.12.012>. Accessed: Sep. 22, 2018. doi: 10.1016/j.apenergy.2010.12.012.

SOARES, J. et al. Scenedesmus sp. cultivation using commercial-grade ammonium sources. Annals of Microbiology. v.68, p.35-45, 2018. Available from: <https:// doi.org/10.1007/s13213-017-1315-x>. Accessed: Aug. 21, 2018. doi: 10.1007/s13213-017-1315-x. 